\title{
Criminological Study of Drug Distribution in Lubuklinggau City
}

\author{
Agustinus Samosir ${ }^{1 *}$ and Anak Agung Sagung Laksmi Dewi ${ }^{2}$ \\ ${ }^{1}$ Universitas Bina Insan Lubuklinggau, Sumatera Selatan-Indonesia \\ ${ }^{2}$ Faculty of Law, Universitas Warmadewa, Denpasar, Bali-Indonesia \\ Email: samosiragustinusmh@gmail.com*
}

Published: 31/08/2021

How to cite:

Samosir, A., \& Dewi, A. A. S. L. 2021. Criminological Study of Drug Distribution in Lubuklinggau City. Sociological Jurisprudence Journal. Volume 4 Issue 2. Page 129 - 133. https://doi.org/10.22225/scj.4.2.2021.129-133

\begin{abstract}
Drug crimes are a serious crime against humanity, which has a tremendous impact, particularly on the young generation. Drug crimes also count as transnational crime, considering that the distribution and trade of drugs are executed illegally across national borders. As a legal state, to uphold the rule of law is to eradicate the distribution and use of narcotics, specifically in Lubuklinggau. This situation became the basis for us to explore the problem: how is the criminology study of drug distribution in Lubuklingau city?. The prevention of drug distribution in Lubuklinggau today needs improvement, particularly in terms of facilities. Advanced detection tool is necessary to improve the prevention of drug trafficking. Professional guidance and prevention efforts are made in various locations, such as government offices, schools, campuses, with supervision from police officers. The enforcement system also needs to give severe punishments to offenders.
\end{abstract}

Keywords: Criminology Study; Drug Trafficking.

\section{INTRODUCTION}

Throughout history, civilizations around the world have known drugs. Initially, drugs were used only for health. But today, the use of drugs has expanded beyond its initial function. Drugs today are used for pleasure as well, which ultimately paralyzes the nerves of human productivity. As a result, people can lose their sense and dignity. Massive illegal distribution of all types of drugs by traffickers poses a serious threat to the nation. It is a concern that humankind must overcome. More importantly, it must become a new nomenclature in crime, namely drug crimes.

In China, the Gil-like, pleasure-inducing material is called opium and destroyed China in the 1840s. The event is known as the Opium War due to Britain's use of opium as a subversive tool. The war lasted from 1839 to 1842 , and Britain emerged as the victor after successfully destroying the opponent's mentality with opium. During Dutch colonialism, the law has prohibited the use of opium. Most of its users came from the middle class and the Chinese.

In its history, Britain sold opium in large quantities to China and then America. Britain also sold opium in large quantities to China through the British East India Company (BEIC) and the Netherlands until it ended in the Opium War in 1839-1942. The war ended in defeat for China, resulting in the opening of ports that allowed opium to enter Sumatra and Java through VOC.

The drug industry was essentially the result of a long series of political revolutions in the 19th century. The industrial revolution was not a series of interconnected developments, culminating in the transformation of the western. Factories developed rapidly due to technological advances and large economic bureaucracy, which emerged to provide the services needed by the industry and the capitalist system. The capitalist system mainly aims for a free market, a medium to sell various industrial products. This system causes a few to gain large profits, while many others get only a little despite working for long hours. 
Print and electronic media often deliver news of the use of narcotics and psychotropic substances and how people from various backgrounds and ages become victims of drug use. Because of that, many people are already familiar with the term drugs. The use of narcotics and psychotropic substances causes psychological paralysis, which results in the loss of ability to reach accomplishment, concentrate, and make decisions.

People may use drugs for economic reasons. Drugs are highly addictive, and people can even commit crimes to fulfill their need for these addictive substances. Drug crimes are a serious crime against humanity and have a tremendous impact, especially on the younger generation. Drug crimes also count as transnational crimes as the illegal distribution and trade of drugs occur across countries.

Indonesia is a legal state. A legal state refers to a state that adheres to the supremacy of law to uphold integrity and justice. Every legal state generally has three fundamentals: the supremacy of the law, equality before the law, and law enforcement that adhere to the law or due process of law. The law in every state has three characteristics: the protection of human rights, an independent judiciary, and adherence to the law in every action that the government and the people take. Therefore, the law is guidance that regulates the order in society and should be adhered to by the people.

To be considered a modern state, a state must accept and implement innovations to give a better life to its people. In a modern legal state, the constitution restricts the democratically formed government's exercise of power. As a result, the government can only exercise its political power.

Law is strongly related to human life. It is born from the interaction and development in society. Furthermore, it plays a role in the relationship between individuals and between groups. Law manifests in this relationship as rules or social norms. As a problem in a pluralistic society, which also has a relation to international society, narcotics and psychotropic substances need to be regulated with statute law. Drug law is future-oriented, and it can encounter drug problems that occur from time to time.

Substantially, the health law has included the use of narcotics and psychotropic substances in the statute. The Health Law Number 36 of 2009 allows drugs and psychotropic substances for health and medical purposes. Despite that, there is a possibility of misuse. Hence, the government regulates the use of narcotics and psychotropic substances by issuing Law Number 35 of 2009 concerning Narcotics and Law Number 5 of 1997 concerning Psychotropic Substances.

Considering the Narcotics Law and the Psychotropic Substances Law, it is clear that law serves to maintain order in society. Law is dynamic, on the basis that it is planned, from a particular situation to a non-juridical goal. Therefore, it is the factors outside the law that maintain the dynamic growth of the law. Law enforcement against narcotics and psychotropic crimes is very aggressive. Despite the effort, drug crimes keep occurring. The difficulty often lies in the neat structure of drug traffickers, which may allow the involvement of current or former law enforcers. As the number of narcotics and psychotropic substances increases, the number of users also increases. Drug users today come from various backgrounds. They come from miserable families, the middle class, and even happy people. Narcotics and psychotropic substances enter from a route located between Thailand, Myanmar, and Laos, also known as the golden triangle. In Indonesia, drugs are circulated using various methods that closely resemble those of the international mafia.

The government has made a great effort to prevent drug use according to the legislation. Wiretapping, covert purchases, and supervision of goods delivery, which allows expeditious investigation, are carried out as part of the prevention effort. Despite that, access to illegal drug distribution remains open. Drug use also keep expanding, even reaching institutions and law enforcers at various ranks. This situation became the basis for us to explore the problem: how is the criminology study of drug distribution in Lubuklingau city?

\section{RESULT AND DISCUSSION}

\section{Definitions of Criminology}

Criminology is a social science that questions all kinds of social phenomena and the scope of the dynamics of meaning. Hence, criminologists have different definitions according to their respective disciplines. 
Criminology is the study of crime. (Hamzah, 1994) defined criminology as a study that examines the causes and prevention of crimes. Bonger, meanwhile, stated that criminology is a study that aims to conduct an extensive investigation of the symptoms of crimes. Mabel Elliot's definition of criminology views crime as any action prohibited and punished by the state as defined in law. Etymologically, the term criminology is derived from "crimen," meaning "accusation" and "logos," meaning "science." Hence, criminology is the study of crime.

Seeing the varying definitions, it is clear that criminology has a broad meaning. Undoubtedly, the study of crime often involves various angles. Some view criminology from the causes of crime, while some others from the behavior in society. Hence, the researcher specified experts' definitions of criminology to make it easier to distinguish and understand.

\section{Theories About the Causes of Crime}

Ralf Dahrendof developed a conflict theory on the perspective that:

Society always experiences change, indicated by continuous contradictions between its elements.

Each element contributes to social disintegration.

Stipulations in society are caused only by coercion of power from above by the ruling group.

Furthermore, the conflict theory considers stipulations in society are due to the coercion of power from above by the ruling group.

To further complement the theories about the causes of crimes, the researcher also provided cultural deviance theories. There are three main theories under cultural deviance theories:

Social disorganization;

Differential association; and

Culture conflict.

In social disorganization theory, the focus is on areas with high crime rates. It also suggests that high crime rates are related to the disintegration of conventional values. Rapid industrialization, increasing immigration, and urbanization are the factors causing this disintegration. The theory suggests that criminals and delinquents, in reality, adhere not to conventional values but to norms that deviate from the value of the dominant group.

\section{Concept of Crime}

Criminal act (delict) comes from Dutch "strafbaarfeit." The term has several definitions, including criminal case, criminal act, punishable act, criminal offense, and delict. Of all these terms, the most appropriate term is delict, derived from Latin "delictum" and "delicta." Van Hamel defined delict as human behavior, which, according to the constitution, is against the law and punishable and shows signs of offense. Legal expert (Lamintang, 1984) translated the term strafbaarfeit into a criminal act. Lamintang defined the term as a deliberate violation of the law by a person who can shoulder accountability for his action by receiving punishment.

\section{Criminalization of Drug Crimes}

Like a time bomb, drug crimes rapidly grow from time to time, reflecting the increasing use of drugs. Drugs use today has become a concern and puts people's lives at risk. Furthermore, Indonesia is known to have the largest illegal drug industry in the world. Drug crimes are extraordinary crimes against humanity that can destroy the entire nation. Drug crimes may also cause a larger crime dimension in Indonesia.

Drug crimes have harmful impacts on various aspects of human life. They affect the national economy, cause repudiation of humanity, and damage the morals of future generations. Ultimately, drugs are dangerous, and the circulation of drugs in Indonesia must stop. History has witnessed the way a drug war destroyed the relations between countries. Hence, drug crimes must receive the utmost attention and systematic treatment from every nation to break the chain of drug crimes. The City Government of Lubuklinggau, in collaboration with the National Narcotics Board of Lubuklinggau City, appointed 5.500 anti-drug activists spread across 72 kelurahan (sub-districts) and counselors in eight 
kecamatan (districts) to encourage drug users to participate in rehabilitation. This appointment aims to lower the number of drug users in Lubuklinggau City. The Acting Head of the National Narcotics Board of Lubuklinggau provides data on achievements concerning the enforcement against drug trafficking in Lubuklinggau as follows.

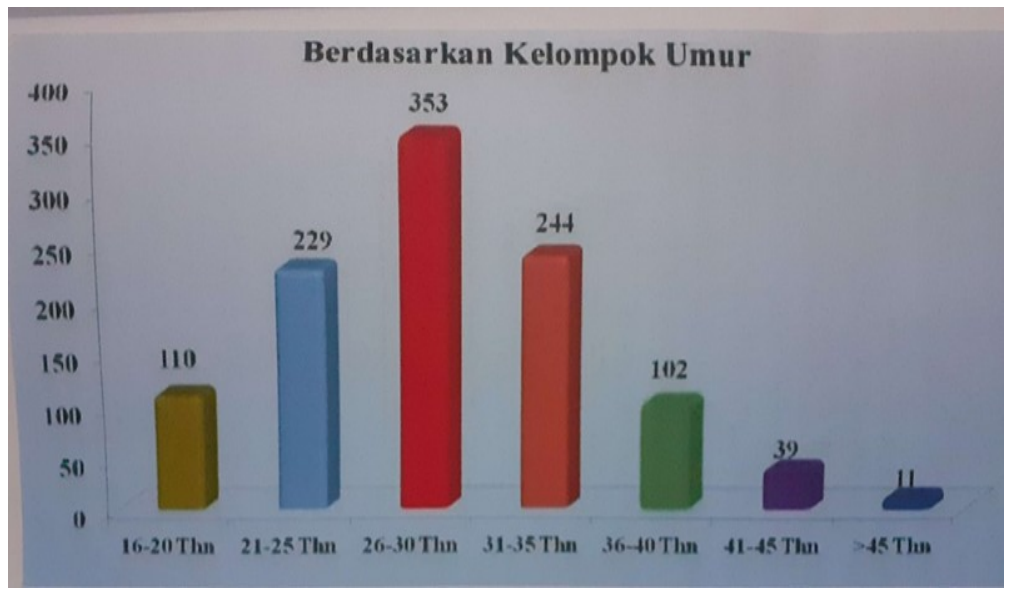

Figure 1

Data on drug abuse by age in Lubuklinggau City

When the users and victims of drugs are adolescents in the developmental stages and also productive adults, the social impacts of drug crimes had on them are enormous. Drug crimes can destroy their future and cause long-term harm to their mental and bodies. But, the enforcement against drug crimes is very complex, causing new complications.

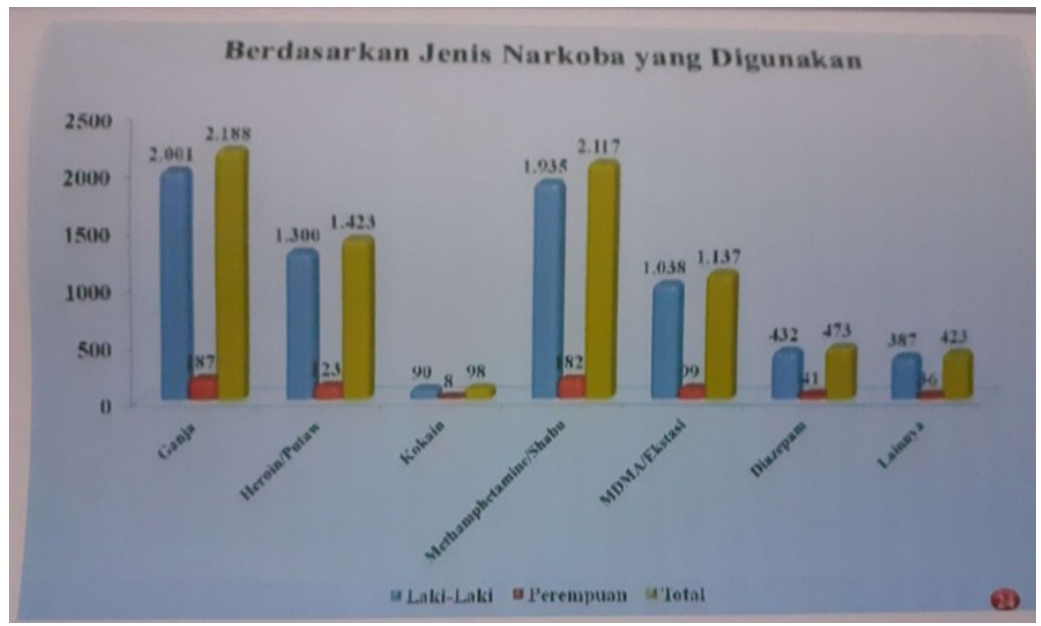

Figure 2

Data on types of drugs used in Lubuklinggau City

Of all types of drugs, marijuana and methamphetamine are the ones used the most in Lubuklinggau. The Narcotics Law and the Psychotropic Substances Law then serve to maintain order in society. Law is dynamic, on the basis that it is planned, from a particular situation to a goal that will be achieved. Law is a tool to realize juridical goals. Hence, it is the factors outside the law that maintain the dynamic nature of the law.

The Narcotics Law and the Psychotropic Substances Law serve to maintain order in society. Law is dynamic, on the basis that it is planned, from a particular situation to a goal that will be achieved. Law is a tool to realize juridical objectives. Hence, it is the factors outside the law that maintain the dynamic nature of the law.

Drug crime enforcement is executed aggressively without discrimination to break the chain of drug distribution. The problem is, the structure of the traffickers is neat, and it may allow current or former law enforcers to be involved. Hence, combating drug crimes becomes complicated and requires complex 
and intricate solutions.

The amount of distributed drugs and the number of drug users keep increasing. Not only do the users come from miserable families, but also middle-class people and happy people. No one is immune from the danger of drug trafficking. Narcotics enter from a route commonly called the golden triangle, located between Thailand, Myanmar, and Laos. Drug trafficking in Indonesia uses various methods, which closely resemble those of the international mafia.

\section{CONCLUSION}

The prevention of drug distribution in Lubuklinggau today needs improvement, particularly in terms of facilities. Advanced detection tool is necessary to improve the prevention of drug trafficking. Professional guidance and prevention efforts are made in various locations, such as government offices, schools, campuses, with supervision from police officers. The enforcement system also needs to give severe punishments to offenders.

\section{References}

Hamzah, A. (1994). Asas-asas Hukum Pidana. Bandung: Rineka Cipta.

Lamintang. (1984). Delik-delik Khusus. Bandung: Tarsito.

Mardani. (2008). Penyalahgunaan Narkoba dalam Perspektif Hukum Islam dan Hukum Pidana Nasional. Jakarta: PT Raja Grafindo Persada

Makarao, M. T., Suhasril., \& Sikumbank, R. F. (2003). Tindak Pidana Narkotika. Bogor: Galia Indonesia.

Soetomo. (1995). Masalah Sosial. Jakarta: Pustaka Jaya. 